\title{
Factors associated with the grief after stillbirth: a comparative study between Brazilian and Canadian women*
}

\author{
Fatores associados ao estado de luto após óbito fetal: estudo \\ comparativo entre brasileiras e canadenses \\ Factores asociados con el estado de duelo después de muerte fetal: \\ estudio comparativo entre brasileñas y canadienses
}

Gisele Ferreira Paris ${ }^{1}$, Francine de Montigny ${ }^{2}$, Sandra Marisa Pelloso ${ }^{3}$

How to cite this article:

Paris GF, Montigny F, Pelloso SM. Factors associated with the grief after stillbirth: a comparative study between Brazilian and Canadian women. Rev Esc Enferm USP. 2016;50(4):546-553. DOI: http://dx.doi.org/10.1590/S0080-623420160000500002

\footnotetext{
* Extracted from the thesis "Luto por óbito fetal: estudo comparativo entre mulheres brasileiras e canadenses", Programa de Pós-graduação em Enfermagem da Universidade Estadual de Maringá, 2015.

${ }^{1}$ Universidade Estadual do Oeste do Paraná, Francisco Beltrão, PR, Brazil.

${ }^{2}$ Université du Quebec en Outaouais, Gatineau, QC, Canada.

${ }^{3}$ Universidade Estadual de Maringá, Departamento de Enfermagem, Maringá, PR, Brazil.
}

\begin{abstract}
Objective: To verify the association between complicated grief and sociodemographic, reproductive, mental, marital satisfaction, and professional support characteristics in women after stillbirth. Method: Cross-sectional study with 26 women who had stillbirth in 2013, living in the city of Maringá, Brazil, and eight women who attended the Centre d'Études et de Recherche en Intervention Familiale at the University of Quebec en Outaouais, in Canada. The instrument was administered as an interview to a small number of mothers of infants up to three months $(n=50)$, who did not participate in the validation study. Results: By applying the short version of the Perinatal Grief Scale, the prevalence of complicated grief in Brazilian women was found to be higher (35\%) in relation to Canadian women (12\%). Characteristics of the Brazilian women associated with the grief period included the presence of previous pregnancy with live birth, absence of previous perinatal loss, postpartum depression, and lack of marital satisfaction. For the Canadians it was observed that $80 \%$ of the women presenting no grief made use of the professional support group. In both populations the occurrence of complicated grief presented a higher prevalence in women with duration of pregnancy higher than 28 weeks. Conclusion: The women that must be further investigated during the grief period are those living in Brazil, making no use of a professional support group, presenting little to no marital satisfaction, having no religion, and of a low educational level.
\end{abstract}

\section{DESCRIPTORS}

Fetal Death; Grief; Obstetric Nursing; Psychometrics; Comparative Study.

\section{Corresponding author:}

Gisele Ferreira Paris

Universidade Estadual do Oeste do

Paraná - Campus Francisco Beltrão

Rua Maringá, 1200

CEP 85605-010 - Francisco Beltrão, PR, Brasil

gfparis18@gmail.com
Received: 12/17/2015

Approved: 07/23/2016 


\section{INTRODUCTION}

Issues related to fetal death, also called stillbirth and born dead, defined as the death of a fetus before or during delivery after 22 weeks of pregnancy, do not receive the same level of attention in relation to the measures to reduce maternal and infant mortality as recommended by the United Nations ${ }^{(1-2)}$.

In recent decades little decrease or stability in the fetal mortality rates has been observed in several countries around the world. Stillbirth rates do not represent an exclusive issue of developing countries. Among developed countries there is a variation in the fetal mortality rates that could be avoided through proper interventions ${ }^{(3-4)}$. In developing countries, although fetal deaths result from the influence of the same circumstances and etiologies as early neonatal mortality, the theme remains poorly researched ${ }^{(1)}$.

Among the strategies adopted to reduce perinatal mortality, the Brazilian government created the Committees for Prevention of Infant and Fetal Death in 2004 in order to monitor infant and fetal deaths and propose interventions to reduce mortality. However, even in cities presenting a high human development index (HDI), which are referenced in health services in relation to the investigation of deaths and the management and planning of actions in health for preventability in the state of Paraná, the fetal mortality trend has remained stable over the last decade ${ }^{(5)}$.

Regarding the perspective of women who have experienced fetal death, studies show that some can get through the loss, but in other cases this process may be very traumatic, generating psychological disturbances ${ }^{(6)}$ such as depression $^{(4,6-7)}$, anxiety ${ }^{(4)}$, posttraumatic stress disorder ${ }^{(6,8)}$, and complicated grief ${ }^{(6,9-10)}$.

Complicated grief was recently recognized as a mental disorder, and its introduction in the diagnoses of the fifth and latest edition of the Diagnostic and Statistical Manual of Mental Disorders (DSM-V) and in the upcoming International Classification of Diseases (ICD-11) $)^{(11)}$ has been proposed. Complicated grief is defined as intense, prolonged, distressing, disabling suffering, which becomes a serious health problem that affects the patient, the family, and even society ${ }^{(11)}$ due to a maladjustment in the rupture of a significant relationship throughout life $\mathrm{f}^{(9)}$.

The manifestations of the development of complicated grief are more common in the female population and after the loss of a child ${ }^{(12)}$; the younger the age of the children ${ }^{(13)}$ and stillbirth $^{(14)}$ the more intense the grief. In relation to stillbirth, women experience a different grief ${ }^{(15)}$, a different form of sorrow, resulting from months of planning and expectations that end in a birth with no vital signs ${ }^{(4)}$, a situation that demands time and support to overcome the loss ${ }^{(6)}$.

For an effective nursing care for women who have experienced stillbirth it is critical to conduct a preliminary investigation of the grief process in order to plan the necessary interventions in each case ${ }^{(2)}$. Less developed countries still do not present an organized proposal of reference public policy in the care related to the grief of women and family members ${ }^{(4)}$. The identification of factors associated with complicated grief in women after stillbirth in two distinct countries through a convention between the postgraduate programs of the universities of the countries creates an opportunity for a specialized professional training in the area of perinatal grief as well as support for grief.

Considering the available literature, studies about grief in women after stillbirth were found to be necessary for purposes of support and revelation of prolonged cases. In this context, for a proper assessment of the grief phenomenon, the present study was proposed with the aim of verifying the association between complicated grief and the sociodemographic, reproductive, mental, marital satisfaction, and professional support characteristics in women after stillbirth.

\section{METHOD}

This was a cross-sectional, descriptive, exploratory study with 26 women that experienced a stillbirth registered in the Mortality Information System (SIM), living in the city of Maringá (PR) in the year 2013, and 18 women that attended the Centre d'Études et de Recherche en Intervention Familiale (CERIF) of the University of Québec in Outaouais, in Gatineau, Quebec, Canada between 2010 and 2014.

Data collection was conducted by applying a form covering the following characteristics: sociodemographic (age of the woman at the time of the loss, marital status, educational level, employment status, religion, religious practice, visits by religious individuals, marriage time), reproductive (gestational age at the loss, previous pregnancies, previous gestational losses, pregnancy planning, and time of the loss), and use or non-use of a professional support group, as well as a self-administered questionnaire covering the mental characteristics (short version of the Perinatal Grief Scale, Edinburgh Postnatal Depression Scale, Anxiety Scale), and marital satisfaction.

Data collection was conducted in Canada between 2010 and 2014 and in Brazil between 2013 and 2014. Women that were not found at the reference addresses for data collection were excluded.

The short version of the Perinatal Grief Scale, translated into Portuguese as "Escala de Luto Perinatal (ELP)", adapted and validated to Brazilian Portuguese and Canadian French $^{(2)}$, presents 33 psychometric characteristics of factors related to the symptoms of adaptation in the loss. It includes signs of grief, sorrow, baby missing, difficulties in performing activities and in relationships with others, and feelings of hopelessness and worthlessness. To assess the psychometric characteristics, the ELP is supported on a Likert-type scale with five options of responses ranging between one and five points, from strongly disagree to strongly agree, with interval between 33 and 165 points $^{(16)}$.

The $\operatorname{ELP}^{(9-10,16)}$ is the instrument that measures the identification of perinatal grief with more accuracy. Originally written in English, it was first applied to a population in the United States ${ }^{(16)}$, and currently it is been being used in research in several countries worldwide ${ }^{(9-10,16)}$.

The Edinburgh Postnatal Depression Scale, translated into Portuguese ${ }^{(17)}$ and French ${ }^{(18)}$, is used to identify postpartum depression. It consists of a scale containing 10 self-administered affirmatives with four options of responses ranging between zero and three points and a total sum between zero and 30 points. The cutoff point used to track moderate or severe depression cases is $\geq 11^{(17)}$. 
The scale used to identify the trait and state of anxiety, translated into Portuguese ${ }^{(19)}$ and French $^{(20)}$, containing 20 items related to what women usually feel in their daily lives and what they feel while answering the instrument. Options of responses are: not a bit; a little; moderate; and a lot. The sum of the scale ranges between 20 and 80 points; the presence of mild anxiety is considered when the score is below 33 points, moderate anxiety when it is between 33 and 49, and severe anxiety when the score exceeds 49 points ${ }^{(19)}$.

For marital satisfaction, four items of the Dyadic Adjustment Scale were used (trust in the partner, thoughts about separation, good marital relationship, and marital happiness), translated into Portuguese ${ }^{(21)}$ and French ${ }^{(22)}$. The instrument is answered through a Likert-type scale ranging between five and zero points representing the perception of life as a couple, and respectively corresponding to the variations between "always", "most of the time", "often", "occasionally", "rarely," and "never." Regarding happiness in the relationship, the scale presents the following options: "extremely happy"; "very happy"; "happy"; "a little sad"; "very sad"; and "extremely sad"(21).

\section{ANALYSIS PROCEDURE}

The cutoff point for the identification of grief consists in the sum exceeding 90 of the ELP for women with complicated grief, and the sum below 90 for women without grief ${ }^{(16)}$.

The odds ratio (OR) with a statistical significance level fixed at $\mathrm{p} \leq 0.05$ through the software Epi Info ${ }^{\circledR} 6.0$ was used to verify the association between grief (dependent variable) and the sociodemographic, reproductive, mental, marital satisfaction, and professional support characteristics of women (independent variables). Subsequently, for a better view, multiple correspondence multivariate analysis was conducted with the main relevant variables associated with grief in the bivariate analysis and support of the literature, consisting in: years of formal education; religious practice; thought about separation; and participation in a professional support group, through the software Statistica 6.0.

Multiple correspondence analysis is a descriptive technique that allows the interpretation of associations between two or more variables for a graphical representation in two axes. The technique is intended to provide an in-depth explanation of the variability of data through the projection of points on a two-dimensional plane, enabling a view of "proximity" patterns between the points and the interpretation of associations between the variables.

For multiple correspondence analysis the variables were labeled with the values 1 (yes) and 2 (no), and two axes ( 1 for the left side and 2 for the right side) were considered in the interpretation. Axis 1 presents the negative answers, which in the present study showed the variables that are not associated with grief, while axis 2 showed the positive answers associated with grief.

The study followed the guidelines for research involving human subjects in accordance with Resolution 466/12 of the National Health Council and was approved by the Research Ethics Committee of the State University of Maringá under protocol 407.840/2013.

\section{RESULTS}

In 2013 a total of 30 stillbirths occurred among mothers living in Maringá. From the addresses on the death certificates registered in the SIM, four women were excluded because they were not living at the provided address, resulting in a total of 26 participants. Among the women that participated in the CERIF between 2010 and 2014, 18 experienced stillbirth. The presence of grief, identified by the ELP, was higher among Brazilians, with a prevalence of $35 \%$ in relation to the prevalence of $12 \%$ for Canadians.

The sociodemographic characteristics and the association with complicated grief after fetal death in Brazilians included age between 20 and 34 years, without a partner, 12 years or less of formal educational, without paid job $(p \geq 0.05)$, without religion, and absence of religious visits $(\mathrm{p} \leq 0.05)$. For the Canadians, complicated grief presented an association with absence of choice of religion, and absence of religious visits was a protective factor for nonmanifestation of complicated grief $(\mathrm{p} \leq 0.05)$ (Table 1$)$.

Table 1 - Bivariate analysis of association between the sociodemographic characteristics of the women that had stillbirth and complicated grief - Maringá, PR, Brazil/Gatineau, QC, Canada, 2015.

\begin{tabular}{|c|c|c|c|c|c|c|c|c|c|c|}
\hline \multirow{3}{*}{ Characteristics } & \multicolumn{4}{|c|}{ Brazilians } & \multicolumn{6}{|c|}{ Canadians } \\
\hline & \multicolumn{2}{|c|}{ With grief } & \multicolumn{2}{|c|}{ Without grief } & \multirow[b]{2}{*}{ OR } & \multicolumn{2}{|c|}{ With grief } & \multicolumn{2}{|c|}{ Without grief } & \multirow[b]{2}{*}{ OR } \\
\hline & $\mathbf{n}$ & $\%$ & $n$ & $\%$ & & $\mathbf{n}$ & $\%$ & $\mathbf{n}$ & $\%$ & \\
\hline \multicolumn{11}{|l|}{ Women's age } \\
\hline 20 to 34 & 6 & 37.5 & 10 & 62.5 & 1.4 & 2 & 15.3 & 11 & 84.7 & - \\
\hline$<20$ ou $\geq 35$ & 3 & 30.0 & 7 & 70.0 & & - & - & 5 & 100.0 & \\
\hline \multicolumn{11}{|l|}{ Marital status } \\
\hline Without a partner & 2 & 50.0 & 2 & 50.0 & 2.1 & - & - & - & - & - \\
\hline With a partner & 7 & 32.0 & 15 & 68.0 & & 2 & 11.0 & 16 & 89.0 & \\
\hline \multicolumn{11}{|l|}{ Educational level } \\
\hline$<12$ years & 7 & 36.8 & 12 & 46.2 & 1.4 & - & & - & & \\
\hline$\geq 12$ years & 2 & 29.0 & 5 & 71.0 & & 2 & 11.0 & 16 & 89.0 & - \\
\hline \multicolumn{11}{|l|}{ Employment } \\
\hline No & 4 & 40.0 & 6 & 60.0 & 1.4 & - & - & 3 & 100.0 & - \\
\hline
\end{tabular}


...continuation

\begin{tabular}{|c|c|c|c|c|c|c|c|c|c|c|}
\hline \multirow{3}{*}{ Characteristics } & \multicolumn{4}{|c|}{ Brazilians } & \multicolumn{6}{|c|}{ Canadians } \\
\hline & \multicolumn{2}{|c|}{ With grief } & \multicolumn{2}{|c|}{ Without grief } & \multirow[b]{2}{*}{ OR } & \multicolumn{2}{|c|}{ With grief } & \multicolumn{2}{|c|}{ Without grief } & \multirow[b]{2}{*}{ OR } \\
\hline & $\mathbf{n}$ & $\%$ & $\mathbf{n}$ & $\%$ & & $\mathbf{n}$ & $\%$ & $\mathbf{n}$ & $\%$ & \\
\hline Yes & 5 & 31.5 & 11 & 68.5 & & 2 & 13.3 & 13 & 86.7 & \\
\hline \multicolumn{11}{|c|}{ Choice of religion* } \\
\hline No & - & - & 1 & 100.0 & - & 1 & 12.5 & 7 & 87.5 & 1.2 \\
\hline Yes & 9 & 36.0 & 16 & 64.0 & & 1 & 10.0 & 9 & 90.0 & \\
\hline \multicolumn{11}{|l|}{ Religious practice } \\
\hline No & 8 & 88.9 & 5 & 29.4 & $19.2+$ & - & - & $4 \ddagger$ & 100.0 & - \\
\hline Yes & 1 & 11.1 & 12 & 70.6 & & 1 & 16.7 & 5 & 83.3 & \\
\hline \multicolumn{11}{|l|}{ Religious visits } \\
\hline No & 7 & 77.8 & 2 & 21.8 & $26.2+$ & 1 & 7.7 & 12 & 92.3 & 0.3 \\
\hline
\end{tabular}

* Catholic or Evangelical religions were identified; $\dagger \mathrm{p} \leq 0,05 ; \ddagger$ Does not apply to the other eight women, as they did not present choice of religion; OR: odds ratio.

In relation to the reproductive characteristics and the association with complicated grief for the Brazilians, the presence of the following factors was observed: previous pregnancy with live-born baby; absence of occurrence of previous loss; and unintended pregnancy. For the Canadians, the occurrence of loss less than one year previously was observed. For both populations the factor associated with complicated grief was gestational age above 28 weeks ( $p \geq 0.05$ ). Exclusively for the Brazilians, complicated grief presented an association with high anxiety $(\mathrm{p} \geq$ $0.05)$ and postpartum depression $(\mathrm{p} \leq 0.05)$ (Table 2).

Table 2 - Bivariate analysis of association between mental and reproductive health characteristics of the women that had stillbirth and complicated grief - Maringá, PR, Brazil/ Gatineau, QC, Canada, 2015.

\begin{tabular}{|c|c|c|c|c|c|c|c|c|c|c|}
\hline \multirow{3}{*}{ Characteristics } & \multicolumn{4}{|c|}{ Brazilians } & \multicolumn{6}{|c|}{ Canadians } \\
\hline & \multicolumn{2}{|c|}{ With grief } & \multicolumn{2}{|c|}{ Without grief } & \multirow[b]{2}{*}{ OR } & \multicolumn{2}{|c|}{ With grief } & \multicolumn{2}{|c|}{ Without grief } & \multirow[b]{2}{*}{ OR } \\
\hline & $\mathrm{n}$ & $\%$ & $n$ & $\%$ & & $\mathbf{n}$ & $\%$ & $n$ & $\%$ & \\
\hline \multicolumn{11}{|l|}{ Gestational age } \\
\hline$\geq 29$ weeks & 4 & 44.4 & $10^{*}$ & 66.7 & 2.5 & 1 & 50.0 & $4+$ & 26.7 & 2.7 \\
\hline$\leq 28$ weeks & 5 & 55.6 & 5 & 33.3 & & 1 & 50.0 & 11 & 73.3 & \\
\hline \multicolumn{11}{|l|}{ Live-born child } \\
\hline Yes & 6 & 66.6 & 7 & 41.2 & 2.8 & 1 & 50.0 & 3 & 18.8 & 4.3 \\
\hline No & 3 & 44.4 & 10 & 58.8 & & 1 & 50.0 & 13 & 81.2 & \\
\hline \multicolumn{11}{|l|}{ Previous losses } \\
\hline No & 9 & 100.0 & 12 & 70.6 & 2.0 & - & - & 10 & 62.5 & - \\
\hline Yes & - & - & 5 & 29.4 & & 2 & 100.0 & 6 & 40.0 & \\
\hline \multicolumn{11}{|l|}{ Intended pregnancy } \\
\hline No & 6 & 66.7 & 11 & 64.7 & 1.0 & - & - & - & - & - \\
\hline Yes & 3 & 33.3 & 6 & 35.3 & & 2 & 100.0 & 16 & 100.0 & \\
\hline \multicolumn{11}{|l|}{ Time of the loss } \\
\hline$<1$ year & 9 & 34.6 & 17 & 65.4 & - & 1 & 33.3 & 2 & 77.7 & 7.0 \\
\hline$\geq 1$ year & - & - & - & - & & 1 & 6.7 & 14 & 93.7 & \\
\hline \multicolumn{11}{|l|}{ Depression } \\
\hline Yes $(\geq 11)$ & 8 & 57.2 & 6 & 42.8 & $14.6 \neq$ & 2 & 50.0 & 2 & 50.0 & - \\
\hline No $(<11)$ & 1 & 8.3 & 11 & 91.7 & & - & - & 14 & 100.0 & \\
\hline \multicolumn{11}{|l|}{ Anxiety } \\
\hline High (50-62) & 6 & 37.5 & 10 & 62.5 & 1.7 & 1 & 11.1 & 8 & 99.9 & - \\
\hline Moderate (42-49) & 3 & 30.0 & 7 & 70.0 & & 1 & 11.1 & 8 & 99.9 & \\
\hline
\end{tabular}

* One woman with undeclared gestational age in the prenatal card and one woman did not get prenatal care; $†$ One Canadian woman with undeclared gestational age; $\ddagger \mathrm{p} \leq$ 0.05; OR: odds ratio.

In relation to marital satisfaction, although the Brazilians presenting grief trust their partners, they had considered separation six times more frequently, presented more chances of not having a good relationship, and reported a low level of marital satisfaction. Marriage duration below five years was found to be associated with grief in both populations. For the Canadians, except for the smaller marriage duration, all of the other characteristics of marital satisfaction presented an association with grief, and $80 \%$ of the Canadian women without grief made use of a professional support group (Table 3) $(p \geq 0,05)$. 
Table 3 - Bivariate analysis of association between the characteristics of marital satisfaction and use of support group of women that had stillbirth and complicated grief - Maringá, PR, Brazil/Gatineau, QC, Canada, 2015.

\begin{tabular}{|c|c|c|c|c|c|c|c|c|c|c|}
\hline \multirow{3}{*}{ Characteristics } & \multicolumn{4}{|c|}{ Brazilians } & \multicolumn{6}{|c|}{ Canadians } \\
\hline & \multicolumn{2}{|c|}{ With grief } & \multicolumn{2}{|c|}{ Without grief } & \multirow[b]{2}{*}{ OR } & \multicolumn{2}{|c|}{ With grief } & \multicolumn{2}{|c|}{ Without grief } & \multirow[b]{2}{*}{ OR } \\
\hline & $\mathbf{n}$ & $\%$ & $\mathbf{n}$ & $\%$ & & $\mathbf{n}$ & $\%$ & $\mathrm{n}$ & $\%$ & \\
\hline \multicolumn{11}{|l|}{ Trust in partner } \\
\hline Yes* & 8 & 38.0 & 13 & 62.0 & 2.4 & 2 & 11.7 & 15 & 88.3 & - \\
\hline Not & 1 & 20.0 & 4 & 80.0 & & - & - & 1 & 100.0 & \\
\hline \multicolumn{11}{|c|}{ Thought about separation } \\
\hline Yes* & 4 & 66.7 & 2 & 33.3 & 6.0 & - & - & - & - & - \\
\hline Not & 5 & 25.0 & 15 & 75.0 & & 2 & 11.1 & 16 & 88.9 & \\
\hline \multicolumn{11}{|c|}{ Good relationship } \\
\hline Not & 3 & 60.0 & 2 & 40.0 & 3.7 & - & - & - & - & - \\
\hline Yes* & 6 & 28.5 & 15 & 71.5 & & 2 & 11.1 & 16 & 88.9 & \\
\hline \multicolumn{11}{|c|}{ Marital happiness } \\
\hline No & 2 & 50.0 & 2 & 50.0 & 2.1 & 1 & 100.0 & - & - & - \\
\hline Yes & 7 & 32.0 & 15 & 68.0 & & 1 & 5.9 & 16 & 94.1 & \\
\hline \multicolumn{11}{|c|}{ Marriage duration } \\
\hline$\leq 5$ years & $6 \neq$ & 85.7 & 1 & 14.3 & 3.2 & 1 & 50.0 & 1 & 50.0 & 1.6 \\
\hline$>5$ years & 11 & 65.0 & 6 & 35.0 & & 6 & 37.5 & 10 & 62.5 & \\
\hline \multicolumn{11}{|c|}{ Professional group } \\
\hline No & 9 & 35.0 & 17 & 65.0 & - & - & - & 8 & 100.0 & - \\
\hline Yes & - & - & - & - & & 2 & 20.0 & 8 & 80.0 & \\
\hline
\end{tabular}

*Yes for always, most of the time, often; $†$ No for occasionally, rarely, never; $\ddagger$ Two women without relationship, $\mathrm{p} \geq 0.05 ; \mathrm{OR}$ : odds ratio.

The multiple correspondence multivariate analysis (Figure 1) identified the profile of the women that had experienced stillbirth and that should be followed by the opposite of the association of characteristics in both axis of the map (right and left) between Brazilians and Canadians.
The women requiring more investigations during the grief period (right axis) are those living in Brazil, making no use of a professional support group, thinking about separation, without religious practice, and presenting 12 years less of formal education.

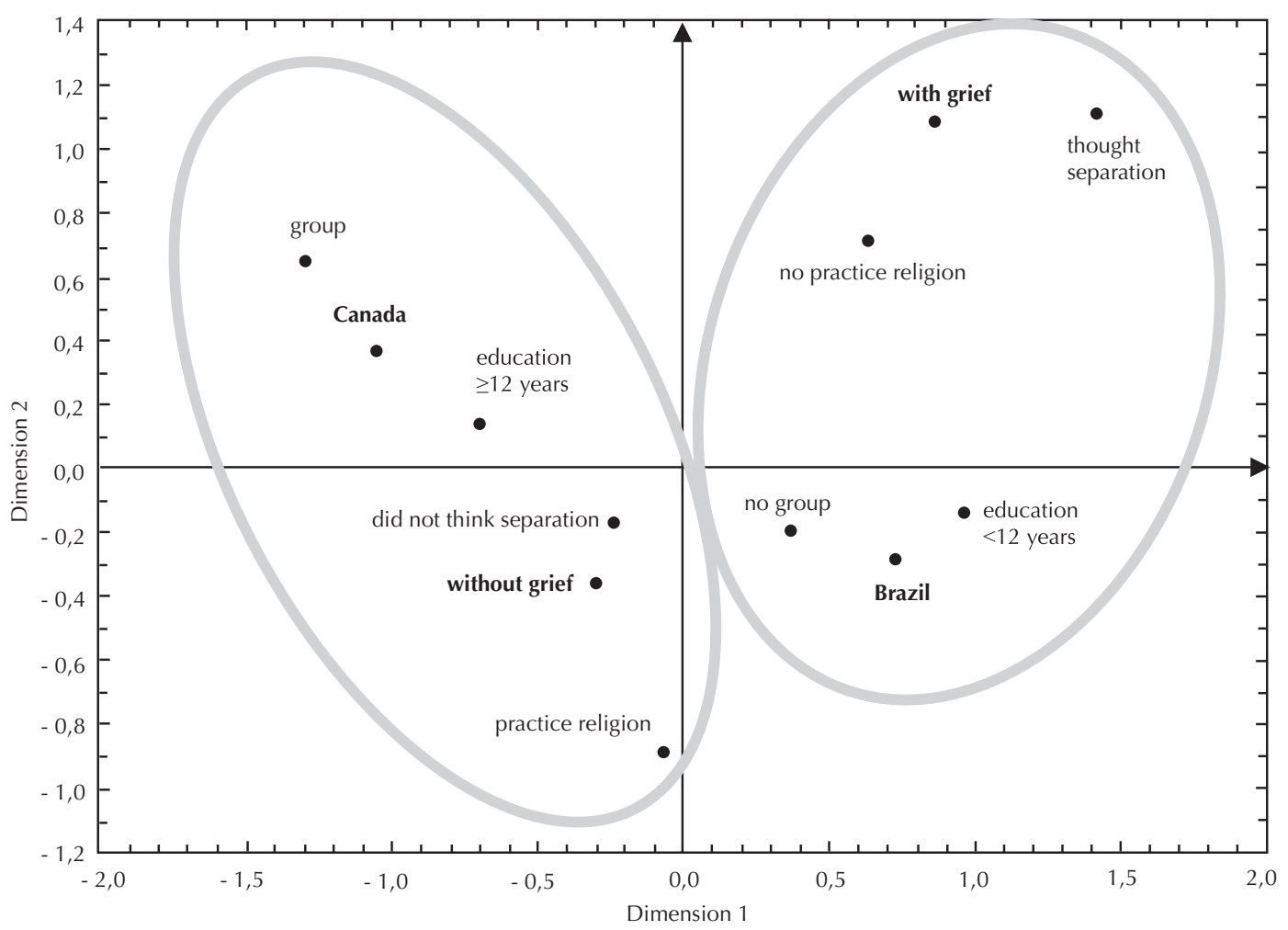

Figure 1 - Map of multiple correspondence multivariate analysis for the variables Brazil, Canada, grief, religious practice, use of support groups, and years of formal education. 


\section{DISCUSSION}

The present study resulted in knowledge in relation to the specific characteristics that are associated or not with complicated grief in women. Thus, it revealed factors that require further investigations in order to enable better professional care and minimize the potential problems in cases of women that have experienced stillbirth. This was the first study of the application of the ELP in the studied populations, generating the possibility of continuous studies in order to verify a change based on time.

The high prevalence of complicated grief and its association with the symptoms of depression and anxiety in Brazilian women was mainly due to the lack of professional support groups to cope with grief, as $80 \%$ of the Canadian women without grief had participated in support groups. Therefore, it was observed that the social need of live-birth parents, supported by professional support in relation to the improvement in the communication of the couple and the quality of the marital relationship ${ }^{(23)}$, is the same as that shown by parents of stillborns ${ }^{(24)}$.

There is a need for recognition of fetal death by society, as the participation of parents in the death process with support from family, friends, and health professionals is critical to coping and overcoming the loss ${ }^{(24)}$. After the occurrence of stillbirth, women control their emotions by themselves; they feel isolated with their problems and concerns, and do not find room to express their affliction, blocking the elaboration of their grief and causing a negative impact on their mental health ${ }^{(4,25)}$.

Health professionals are able to offer the possibility of memories (physical and visual contact, hair, fingerprints, toes, etc.) of the stillborn to the parents, but they need training to secure and understand the support necessary to this situation ${ }^{(24,26)}$. Coping with grief by parents achieves better results when they have the opportunity to meet their babies $^{(27)}$. The acts of seeing and holding the baby are associated with fewer symptoms of posttraumatic stress ${ }^{(8)}$.

A need for disclosure of the experiences of professional health groups with parents that lost their babies and who were able to build a culture of support, affection, and respect for the grief of bereaved parents was observed. Allowing parents to publicly share their difficult stories and learn what can be done in relation to coping with this suffering may possibly help to prevent unnecessary deaths of other children ${ }^{(4,26)}$.

The difference in the level of development between the countries may be observed in the educational level of the women. In Brazil, most women presented with fewer years of formal education and had no paid work; in Canada, all of the women had more years of formal education and most of them had paid work. Religious practice or choice is another question that is directly related to the culture, presenting with a lower prevalence in Canada in relation to Brazil, a predominantly Christian country. In Brazil, women usually have a choice of religion, but they do not practice it, and religious visits were pointed out as an element that contributes to coping with grief.

There was a similarity between the two countries in relation to the higher presence of complicated grief when the duration of the pregnancy exceeded 28 weeks, pointing out that the maternal investment tends to be higher in the final stage of the pregnancy. The presence of grief in multipara Brazilian women with an absence of perinatal losses and the period smaller than one year for Canadians reveal the need for care in each reality, as in another population the association of mental health complications was verified in relation to the period higher than one year after loss, including multipara women and the presence of previous induced abortion cases ${ }^{(8)}$.

The type of study is included among the limitations of this study. Although the universe of the study includes a small number of participants, the population included all of the women that experienced fetal death in 2013, and statistical tests presented consistent results.

\section{CONCLUSION}

The present study evidenced the main factors that deserve to be investigated in the identification of grief in women that experienced stillbirth: women living in Brazil; making no use of a professional support group; without marital satisfaction; without religious practice; and with fewer years of formal education.

Brazilians require more attention from health professionals, support by nurses in their psychic processes, and multidisciplinary work in health services and maternity wards so that the psychic affliction of these women may be deemed legitimate. Unlike Canada, in Brazil there is still little and only isolated professional support group references for these women.

The comparison of factors associated with grief after stillbirth among Brazilian and Canadian women expanded the understanding of the occurrence of grief, provided knowledge on the differences and similarities of stillbirthrelated grief between distinct countries, and brought evidence of the need to update the technical and university curriculum regarding the preparation and training for professional work in cases of manifestations of this type of loss.

\section{RESUMO}

Objetivo: Verificar a associação entre o luto complicado e as características sociodemográficas, reprodutivas, mentais, de satisfação conjugal e apoio profissional em mulheres após óbito fetal. Método: Estudo transversal com 26 mulheres que tiveram óbito fetal no ano de 2013 residentes no município de Maringá, Brasil, e 18 mulheres participantes do Centre d'Études et de Recherche en Intervention Familiale, na Universidade do Quebec em Outaouais, no Canadá. Resultados: Por meio da aplicação da versão curta da Perinatal Grief Scale, a prevalência de luto complicado foi maior nas brasileiras (35\%) em relação às canadenses (12\%). As características das brasileiras associadas ao luto complicado foram a presença de gestação anterior com filho nascido vivo, não ocorrência de perda perinatal anterior, depressão pós-parto e não satisfação conjugal. Para as canadenses, foi observado que $80 \%$ das mulheres sem luto utilizaram grupo 
profissional de apoio. Nas duas populações a ocorrência do luto complicado foi mais frequente nas mulheres com duração na gestação maior que 28 semanas. Conclusão: As mulheres que mais devem ser investigadas no estado de luto são as que moram no Brasil, que não utilizam grupo profissional de apoio, não têm satisfação conjugal, não praticam religião e têm menor escolaridade.

\section{DESCRITORES}

Morte Fetal; Pesar; Enfermagem Obstétrica; Psicometria; Estudo Comparativo.

\section{RESUMEN}

Objetivo: Verificar la asociación entre el luto complicado y las características sociodemográficas, reproductivas, mentales, de satisfacción conyugal y apoyo profesional en mujeres después de muerte fetal. Método: Estudio transversal con 26 mujeres que pasaron por muerte fetal en el año de 2013 residentes en el municipio de Maringá, Brasil, y 18 mujeres participantes en el Centre d'Études et de Recherche en Intervention Familiale, en la Universidad de Quebec en Outaouais, Canadá. Resultados: Mediante la aplicación de la versión corta de la Perinatal Grief Scale, la prevalencia de luto complicado fue mayor en las brasileñas (35\%) con relación a las canadienses (12\%). Las características de las brasileñas asociadas con el luto complicado fueron la presencia de embarazo anterior con hijo nacido vivo, no ocurrencia de pérdida perinatal anterior, depresión post parto y no satisfacción conyugal. Para las canadienses, se observó que el 80\% de las mujeres sin luto utilizaron grupo profesional de apoyo. En ambas poblaciones, la ocurrencia del luto complicado fue más frecuente en las mujeres con duración de embarazo mayor que 28 semanas. Conclusión: Las mujeres que más se deben investigar en el estado de luto son las que viven en Brasil, que no utilizan grupo profesional de apoyo, no tienen satisfacción conyugal, no practican religión y tienen menor escolaridad.

\section{DESCRIPTORES}

Muerte Fetal; Pesar; Enfermería Obstétrica; Psicometría; Estudio Comparativo.

\section{REFERENCES}

1. Frøen JF, Friberg IK, Lawn JE, Bhutta ZA, Pattinson RC, Emma R, et al.; Lancet Ending Preventable Stillbirths Series study group. Stillbirths: progress and unfinished business. Lancet. 2016;387(10018):574-86.

2. Paris GF, DeMontigny F, Pelloso SM. Adaptação transcultural e evidências de validação da Perinatal Grief Scale. Texto Contexto Enferm. 2016;25. In press.

3. Flenady V, Wojcieszek AM, Middleton P, Ellwood D, Erwich JJ, Coory M, et al. Stillbirths: recall to action in high-income countries. Lancet. 2016;387(10019):691-702

4. Scott J. Stillbirth: breaking the silence of a hidden grief. Lancet. 2011;377(9775):1386-8.

5. Brasil. Ministério da Saúde. DATASUS. Informações de Saúde. Estatísticas Vitais. Óbito fetal [Internet]. Maringá; 2014 [citado 2015 fev. 22]. Disponível em: http://tabnet.datasus.gov.br/cgi/deftohtm.exe?sim/cnv/fet10pr.def

6. Hutti MH, Armstrong DS, Myers JA, Hall LA. Grief intensity, psychological well-being, and the intimate partner relationship in the subsequent pregnancy after a perinatal loss. J Obstet Gynecol Neonatal Nurs. 2015;44(1):42-50.

7. Susil Kulathilaka S, Hanwella R, Silva VA. Depressive disorder and grief following spontaneous abortion. BMC Psychiatry [Internet]. 2016 [cited 2016 Apr 21];16:100. Available from: http://www.ncbi.nlm.nih.gov/pmc/articles/PMC4830021/

8. Gravensteen IK, Jacobsen EM, Rådestad I, Sandset PM, Ekeberg O. Women's experiences in relation to stillbirth and risk factors for longterm post-traumatic stress symptoms: a retrospective study. BMJ Open. 2013;3(10):e003323.

9. Johnson OP, Langford RW. A randomized trial of a bereavement intervention for pregnancy loss. J Obstet Gynecol Neonatal Nurs. 2015;44(4):492-9.

10. Ratislavová K, Kalvas F, Beran J. Validation of the czech version of the perinatal grief scale. Cent Eur J Nurs Midw [Internet]. 2015 [cited 2015 Aug 7];6(1):191-200. Available from: http://periodika.osu.cz/cejnm/dok/2015-01/3-ratislavova-kalvas-beran.pdf

11. Prigerson HG, Horowitz MJ, Jacobs SC, Parkes CM, Aslan M, Goodkin K, et al. Correction: prolonged grief disorder: psychometric validation of criteria proposed for DSM-V and ICD. PLoS Med. 2013;10(12):101371.

12. Kersting A, Brahler E, Glaesmer H, Wagner B. Prevalence of complicated grief in a representative population-based sample. J Affect Disord. 2011;131(1-3):339-43.

13. Zetumer S, Young I, Shear MK, Skritskaya N, Lebowitz B, Simon N, et al. The impact of losing a child on the clinical presentation of complicated grief. J Affect Disord. 2015;170:15-21.

14. Kersting A. Peripartum depression and grief after pregnancy loss: special problem areas in obstetrics [abstract]. Nervenarzt. 2012;83(11):1434-1 .

15. Murphy S. Reclaiming a moral identity: stillbirth, stigma and 'moral mothers'. Midwifery. 2012;28(4):476-80.

16. Potvin L, Lasker JN, Toedter LJ. Measuring grief: a short version of Perinatal Grief Scale. J Psychopathol Behav Assess. 1989;11(1):29-45.

17. Santos IS, Matijasevich A, Tavares BF, Barros AJD, Botelho IP, Lapolli C, et al. Validation of the Edinburgh Postnatal Depression Scale (EPDS) in a sample of mothers from the 2004 Pelotas Birth Cohort Study. Cad Saúde Pública. 2007;23(11):2577-88.

18. Guedeney N, Fermanian J. Validation study of the French Version of the Edinburgh Postnatal Depression Scale (EPDS): new results about use and psychometric properties. Eur Psychiatry. 1998;13(2):83-9.

19. Sand ICPV, Girardon-Perlini NMO, Abreu SM. Ansiedade de familiares de parturientes durante o processo de parto. Cienc Cuid Saúde. 2011;10(3):474-81. 
20. Gauthier J, Bouchard S. Adaptation canadienne-française de la forme révisée du State-Trait Anxiety Inventory de Spielberger. Can J Behav Sci. 1993;25(4):559-78.

21. Hernandez JAE. Avaliação estrutural da escala de ajustamento didático. Psicol Estud. 2008;13(3):593-601.

22. Baillargeon J, Dubois G, Marineau R. Traduction française de I'Echelle d'ajustement dyadique. Can J Behav Sci. 1986;18(1):25-34.

23. Caponi I. L'anxiété paternelle et maternelle postnatale et ses liens avec les dimensions relationnelles [abstract]. Neuropsychiatr Enfance Adolesc. 2015;63(1):9-16.

24. Flenady V, Boyle F, Koopmans L, Wilson T, Stones W, Cacciatore J. Meeting the needs of parents after a stillbirth or neonatal death. BJOG. 2014;121Suppl 4:137-40.

25. Andersson IM, Nilsson S, Adolfsson A. How women who have experienced one or more miscarriages manage their feelings and emotions when they become pregnant again - a qualitative interview study. Scand J Caring Sci. 2012;26(2):262-70.

26. Roberts LR, Montgomery S. Mindfulness-based Intervention for Perinatal Grief after Stillbirth in Rural India. Issues Ment Health Nurs. 2015;36(3):222-30.

27. Koch C, Santos C, Santos MR. Study of the measurement properties of the Portuguese Version of the Well-Being Questionnaire12 (W-BQ12) in women with pregnancy loss. Rev Latino Am Enfermagem. 2012;20(3):567-74.

Financial support

Coordenação de Aperfeiçoamento de Pessoal de Nível Superior (CAPES). Process no. 99999.011586/2013-03. 